\title{
Assessment of Dapitan City's Tourism Resources: Basis for the Development of Tourism Plan
}

\author{
Lovelle Pallega \\ Assistant Professor, Jose Rizal Memorial State University, Dapitan City \\ (In collaboration with the Technical Working Group of Dapitan City's Tourism Development Plan)
}

\begin{abstract}
Recognizing the role of tourism in achieving the sustainable development goals, the local government unit of Dapitan City aims to unlock its potential and opportunities through its tourism development plan. As an initial step, this study was conducted to assess the tourism resources of Dapitan City. A mix of quantitative and qualitative approaches were employed in gathering the data which includes a series of focus group discussions (with the different stakeholders) site evaluation survey, informal interviews, site visits and data mining of secondary data. The findings revealed that Dapitan City is endowed with rich natural and cultural heritage which are its greatest assets in promoting tourism. Most of the tourism sites are accessible and have good quality of surroundings but have poor basic utilities and onsite facilities available. Market demand is high from domestic visitors but low in terms of foreign markets. The number of tourism enterprises is limited in relation to demand. Despite being tagged by the negative image of the name "Zamboanga",Dapitan City remains to be one of the safest places to visit. Therefore, tourism industry if properly planned and managed has the ability to stimulate local economic growth, social welfare, and preserve the natural and cultural resources of the city. The study recommends that future developments in tourism shall be focused on the niche of ecotourism, heritage tourism and agritourism.
\end{abstract}

Keywords: tourism, tourism development plan, assessment, tourism resources, Dapitan City

\section{Introduction}

Tourism encompasses all activities of people outside their usual environment whether it may be for business, personal, leisure or other purposes (unwto.org, 2008). With a very broad scope, tourism undeniably demonstrates its capacity to support job creation, promote inclusive social integration, generate livelihood and improve human well-being (UNWTO, 2019). According to the World Travel and Tourism Council (WTTC), in (2017), tourism accounted for about 10.4\% (USD 8 trillion) of global Gross Domestic Product (GDP), 5\% (USD 1 trillion) of total investments, 7\% (USD 1.5 trillion) of the world's exports, and 1 in 10 jobs (313 million jobs) in the global economy. International tourist arrivals grew by $7 \%$ in 2017 , surpassing the consistent trend of $4 \%$ growth since 2010 (WTB, 2017). That is why developed and developing countries are strategizing on how to maximize tourism potentials (Kisi, 2019) to attract large number of visitors who are willing to pour out their hard-earned money into the small, medium and large enterprises in the host countries. Basically, these appropriate and effective strategies can be developed by first assessing the tourism resources of the destination (Nasa \& Hassan, 2016).

The destination's tourism development is key to maintaining sustainable tourism and while some destinations do this very well, others (often developing countries), fail to recognise the importance of effective tourism development planning (Zhao, 2015). On the basic level, developing tourism involves creating plans and strategies to increase/develop/encourage tourism for a destination. Evaluation of tourism development potential (TDP) is a critical step and a crucial foundation for sustainable tourism development (Chen, et al., 2021). Inventorying and identifying local available tourism resources are the first tasks in developing a tourism plan which should include tourism attractions and basic tourism infrastructure (Travis, 2011) 
On the other hand, tourism development and promotion are among the functions of local government units (LGUs) as mandated by the Local Government Code of 1991 (RA 7160) (DOT, 2017). In the last quarter of 2019, the Dapitan City's LGU initiated the call of developing a local tourism plan to enhance tourism local resources and leverage on the economic benefits it can provide to the local community. In order to develop a comprehensive and effective plan, it is imperative to have a complete and detailed picture of the current tourism situation and its potentials and this can be done through tourism profiling. Thus, the main purpose of this study is to assess the tourism resources and assets in Dapitan City and be able to illustrate a situationer of the industry basis for the development of a five-year tourism development plan.

Dapitan City, located in the south-western part of Mindanao in the province of Zamboanga del Norte with geographical coordinates at $8939 \mathrm{~N}$ and $123^{\circ} 25^{\circ} \mathrm{E}$. It is bound on the north by the Sulus Sea and shares territorial boundaries with the city of Dipolog and the municipalities of Rizal, Sibutad, La Libertad, Piñan, Mutia and Polanco. The city's land area of 39053 hectares is divided among 50 barangays of which eight (8) are in the urban center or within the so-called island población, 13 are along the coast, 27 are inland and two are island barangays.

Tagged as "The Shrine City of the Philippines", it holds a significant part of the Philippines' history as the place of exile of the national hero, Dr. Jose P. Rizal. The four-year stay (July 24, 1892 - July 31, 1896) of Rizal brought meaningful contributions to the economic, socio-cultural and environmental welfare in this small remote town which now became its major tourist destination attracting thousands of visitors every year. Aside from the historical sites that are widely distributed in the city proper, it also possess clean and clear white sand beaches, sacred mangrove forests, numerous waterfalls, untouched caves, and of course the unbeatable hospitality and friendliness of its people. Dapitan City has a great potential of becoming a sustainable tourism destination. Thus, tourism activities has to be well-planned and managed to achieve the true essence of sustainability which is preserving and conserving natural, historical, cultural assets while maximizing income opportunities for community residents, thus providing inclusive economic growth to the destination (Mencias, 2017).

This study utilized the Tourism Planning Guidebook published by by the Department of Tourism (DOT) developed through the collaborative efforts among DOT, Department of the Interior and Local Government (DILG) and Department of Environment and Natural Resources (DENR) with the funding support provided by the Government of Canada thru the Local Governance Support Program for Local Economic Development (LGSP-LED) project and the United Nations Development Programme (UNDP) thru the Biodiversity Partnership Project (BPP) and the Center for Governance of the Development Academy of the Philippines (DAP). This Tourism Guidebook has been developed as one of the support mechanisms to "enhance the capability of LGUs to monitor and administer tourism activities, and enforce tourism laws, rules and regulations in their respective jurisdiction." The guidebook was used in developing the inventory of tourism attractions in Dapitan City.

In addition, the Tourism Rapid Assessment (TRA) Manual developed by DOT (2017) was used as a supplementary tool in establishing the market profile in terms of visitor arrivals, top markets; and key support infrastructures and services such as transportation, accommodation, education, peace and security. TRA is a tool for tourism development planning as it draws on multiple evaluation methods and techniques for quick and systematic data collection even with limited time in the field. It also highlights important data and identifies possible issues that must be addressed in the development of tourism sites. The TRA may also contribute to developing tourism product development, and creating local databases.

This study aims to achieve the following objectives: 1 . To develop an inventory of the tourism resources and assets in Dapitan City; 2. To describe the destination's market profile; 3. To provide a situationer of the City's tourism industry

\section{Methodology}

The study employed a mix of quantitative and qualitative approaches to describe the profile of tourism industry in Dapitan City. Various data gathering techniques were used such as focus group discussions (the 
group was composed of various representatives from the different local government offices, local barangay officials, private sector representatives, people's organization, and PNP) to generate the list of existing, emerging, and potential sites for tourism. Five main categories of attractions were then identified.

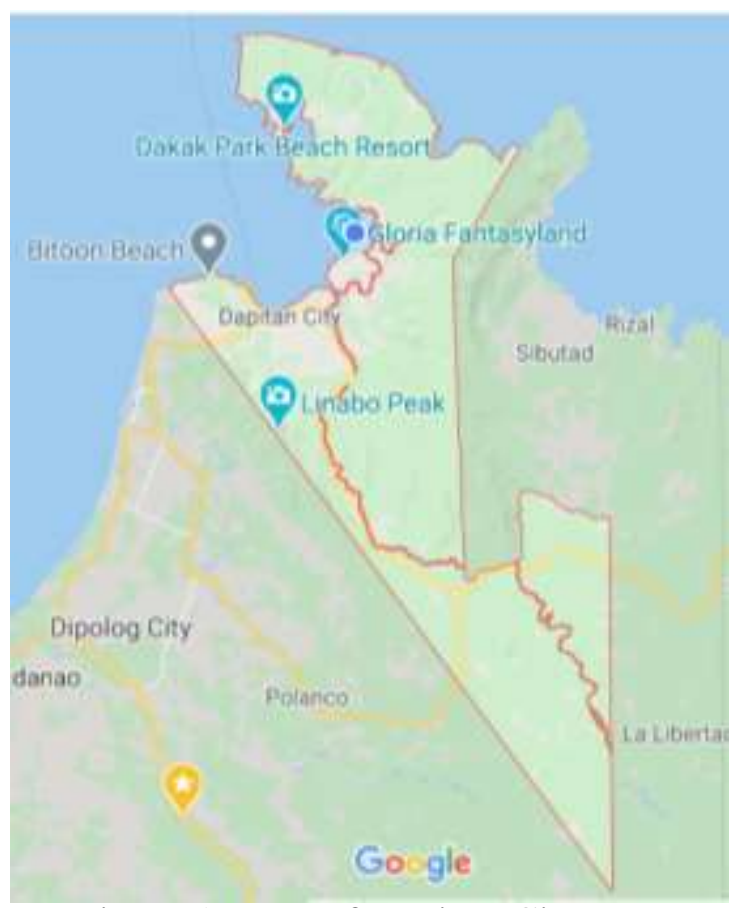

Figure 1. Map of Dapitan City

Source: Google Maps

Site evaluation was conducted using the process suggested from the Tourism Planning Guidebook developed by DOT (2017) to determine which site(s) have the greatest or least potential for tourism based on seven criteria: uniqueness and natural beauty, historical/cultural value, accessibility, availability of basic utilities, availability of onsite facilities, ownership of property, and quality of surroundings. Site visit and further sessions of focus group discussion from different stakeholders was also performed to validate the primary data and identify current issues and concerns related to tourism activities.

Further, data mining techniques was applied to gather secondary data from different information sources such as the City Tourism Office (CTO), Licenses and Business Permits Office (LBPO), City Engineering Office (CEO), City Planning and Development Office (CPDO), City Agriculture Office (CAO), City Council of Heritage, Culture and the Arts (CHCA). Site visits and informal interviews were also conducted among local government and barangay officials, community residents, tour guides, and some owners of local tourism enterprise.

\section{Results and Discussions}

\section{Inventory of Tourism Attractions in Dapitan City}

Dapitan City boosts its natural attractions of pristine beauty and rich historical and cultural values where tourists cannot find in other places. Table 1 presents the inventory of forty tourist attractions in Dapitan City divided into five major categories: eight (7) Natural Heritage, eleven (12) Built Heritage, seven (7) Manmade, (5) Cultural Events, and (9) Ecotourism sites. For this paper, Natural heritage refers to natural features, geological, and physiological formation and delineated areas that constitute the habitat of threatened species of animals and plants and natural sites of value from the point of view of science, conservation or natural beauty (UNESCO, 2009). 
Table 1. Inventory of Tourist Attractions in Dapitan City

\begin{tabular}{|c|c|}
\hline Category & Site/Attraction \\
\hline Natural Heritage & $\begin{array}{l}\text { 1. Dapitan Bay } \\
\text { 2. Beaches } \\
\text { 3. Taguilon Cove } \\
\text { 4. Ambakon Spring and Green Resort } \\
\text { 5. Dapitan River } \\
\text { 6. Ilihan Hill } \\
\text { 7. Mt. Lab } \\
\end{array}$ \\
\hline Built Heritage & $\begin{array}{l}\text { 8. Rizal Shrine Park and Museum } \\
\text { 9. City Plaza } \\
\text { 10. Relief Map of Mindanao } \\
\text { 11. St. James Church } \\
\text { 12. Grotto of Our Lady of Lourdes } \\
\text { 13. Former Church Convent (now the RMI Library) } \\
\text { 14. Parochial School } \\
\text { 15. Old City Hall } \\
\text { 16. Former Rizal Memorial District Hospital } \\
\text { 17. Don Aniano Adasa Heritage House } \\
\text { 18. Gabaldon Building } \\
\text { 19. Spanish Escalon }\end{array}$ \\
\hline Man-made & $\begin{array}{l}\text { 20. Punto del Disembarco de Rizal } \\
\text { 21. Sta. Cruz Marker } \\
\text { 22. Dakak Park and Beach Resort } \\
\text { 23. Gloria de Dapitan and Fantasyland } \\
\text { 24. New Government Center } \\
\text { 25. Dapitan City Aquamarine Park } \\
\text { 26. Barcelona Spring Farm }\end{array}$ \\
\hline Cultural Events & $\begin{array}{l}\text { 27. Sinug festival } \\
\text { 28. Kinabayo festival } \\
\text { 29. Handuraw Festival } \\
\text { 30. Balanghoy Festival } \\
\text { 31. Bangus Festival }\end{array}$ \\
\hline Ecotourism & $\begin{array}{l}\text { 32. Marine Sanctuary } \\
\text { 33. Aliguay Island Landscape and Seascape Protected Area } \\
\text { 34. Selinog Island Landscape and Seascape Protected Area } \\
\text { 35. Jose Rizal Memorial Landscape and Seascape Protected Area } \\
\text { 36. Ilihan Hill } \\
\text { 37. Mt. Tapi } \\
\text { 38. Liboran River } \\
\text { 39. Ambogok Watershed } \\
\text { 40. Talayaman Watershed }\end{array}$ \\
\hline
\end{tabular}

Built Heritage refers to buildings, artifacts, and/or structures that are of historic, aesthetic architectural or cultural significance. and should include natural features within such areas or precincts of environmental significance or scenic beauty such as sacred groves, hills, hillocks, water bodies, open areas, wooded areas, etc. It must be recognized that the cultural landscape around heritage site is critical for the interpretation of the stie and its built heritage and thus is very much an integral part of it (INTACH, 2016). 
Man-made attractions refer to those any type of structure built by humans which can entice visitors. While cultural events refer to annual activities conducted by the city or barangay that is reflective of the culture and commemorative of the significant part of the history. This includes the famous crowd drawer Kinabayo festival, Handuraw Festival, Sinug Festivals. Other cultural events that are celebrated in the barangays are the Balanghoy and Bangus festivals.

Ecotourism site(s) refers to protected areas as declared by the DENR that are considered as tourist attractions of the city because it offers the richness of nature which is highly sought by many. There are currently four protected areas, two of which are island barangays, 1 marine sanctuary and 1 is situated near the town proper.

Figure 2 presents the accommodation capacity of Dapitan City. As of 2018 survey, there a total of 26 accommodation establishments which are broken down as follows: 2 hotels, 5 beach resorts, 14 pension houses, 3 lodging houses, and 2 inns (please see Table 2 for the inventory list of accommodation establishments). The city only has a total of 422 rooms where tourists can spend their night(s) and a total of 641 employees of which 356 are female and 285 male workers.

Figure 2. Accommodation Capacity Survey of Dapitan City (2018)

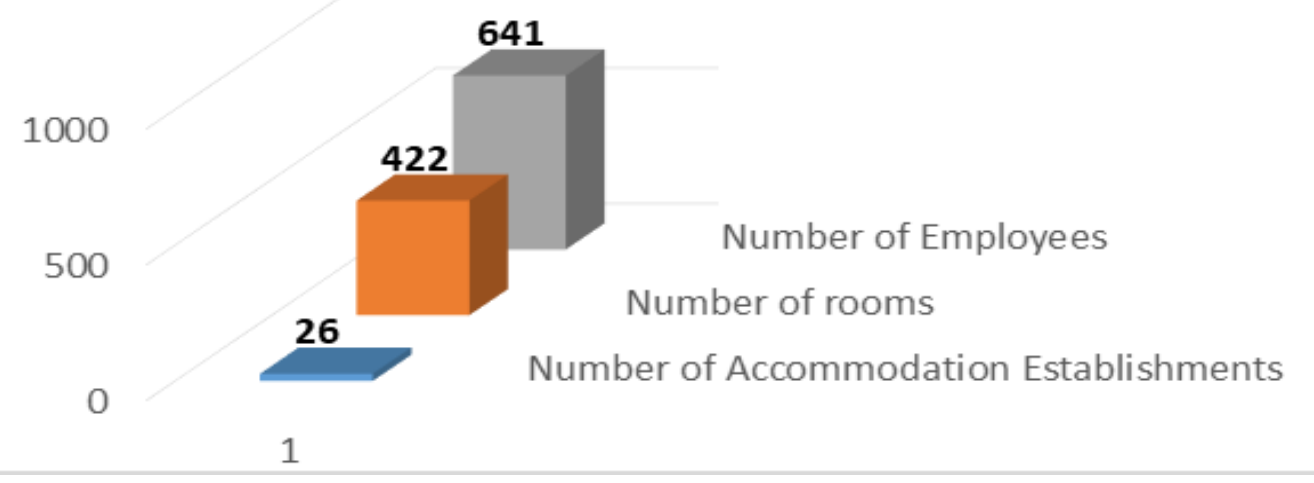

Source: Dapitan City Tourism Office, 2019

Considering the number of visitors, the number of rooms and the number of workers is relatively low. Further, the ratio between the number of workers and number of rooms is $2: 1$ which can be described as low. From the data, it can be inferred that there is a need to add the number of rooms to cater to a much larger number of guests especially during big events and/or conventions.

Moreover, accommodation facilities, services and amenities should also be improved and upgraded to provide a wider selection of modest accommodations services. Accommodation sector is a major element that could affect the entire travel experience of tourists (Wang et al., 2019). Tourists would always want to stay longer in a destination if they get a comfortable and sound sleep coupled with excellent hospitality service (Lopez et al., 2019).

Table 2 presents the inventory of accommodation establishments in Dapitan City duly registered at the Business Permits and Licensing Office for the year (2018). It can be seen that although emerging sites are located in the coastal barangays, most of the establishments are located in the city proper. In addition, most of the accommodation establishments only offer the basic room facilities and amenities. 
Table 2. Inventory of the Accommodation Establishments in Dapitan City (2018)

\begin{tabular}{|c|c|c|}
\hline Nature & Establishment/ Facilities & Location \\
\hline Hotel & 1. Dapitan City Resort Hotel & Sunset Blvd, Dawo \\
\hline Hotel & 2. The White House Dapitan Hotel & Brgy. Dawo \\
\hline Beach Resort & 3. Cool-J Beach Beach Resort & Brgy. Sicayab Bucana \\
\hline Beach Resort & 4. Dakak Park \& Beach Resort & Brgy. Taguilon \\
\hline Beach Resort & 5. Jacinth Beach & Brgy. Canlucani \\
\hline Beach Resort & 6. Sangha Beach & Brgy. Carang \\
\hline Beach Resort & 7. Taguilon Hidden Beach & Brgy. Taguilon \\
\hline Pension House & 8. Alexandra By The Sea Suites and Garden & Sunset Blvd, Dawo \\
\hline Pension House & 9. Bajamunde Farms Pension House & Sunset Blvd, Dawo \\
\hline Pension House & 10. Barcelona Spring Farm & Brgy. Barcelona \\
\hline Pension House & 11. D’Hampton Inn & Road 17, Dawo, \\
\hline Pension House & 12. IAP's Pension House & Brgy. Dawo \\
\hline Pension House & 13. Janas Pension House & Brgy. Sta. Cruz \\
\hline Pension House & 14. La-Bella Visitacion Suite & Brgy. Sta. Cruz, \\
\hline Pension House & $\begin{array}{l}\text { 15. Lorenzo Tan Multi-Purpose } \\
\text { Cooperative }\end{array}$ & Brgy. Sta. Cruz \\
\hline Pension House & 16. Monina's Pension House & Brgy. Dawo \\
\hline Pension House & 17. Monina's Pension House 1 & Brgy. Potol \\
\hline Pension House & 18. Roning's Pension House & Brgy. Dawo \\
\hline Pension House & 19. Travelbee Heritage Inn & Brgy. Dawo \\
\hline Pension House & 20. Villa Pilar Pensione & Sunset Blvd. Dawo \\
\hline Pension House & 21. Wilfredo's Traveller's Inn & Brgy. Polo \\
\hline Lodging House & 22. Dawo Lodging House & Brgy. Dawo \\
\hline Lodging House & 23. Derick's Chateau & Brgy. Sta. Cruz \\
\hline Lodging House & 24. Harohoy sa Baybayon Beach Resort & Brgy. Dawo \\
\hline Inns & 25. Madzvie Pensionne & Brgy. Dawo \\
\hline Inns & 26. Raquel's Pension House & Brgy. Dawo \\
\hline
\end{tabular}

Source: Business Permits and Licensing Office

Dapitan is gifted with a beautiful nature that magnets tourists, and the accommodation sector should be proactive in creating unique facilities and services that would complement the assets of the destination. Accommodation establishments located in front of Dapitan bay could possibly develop recreational facilities and water sport activities so that guests can have a fun-filled experience making their stay worthwhile. Offering more enjoyable activities to tourists than just sight-seeing could make them stay longer, and staying longer means more economic opportunities for both workers and the establishments.

As seen in Table 3, there were 19 souvenir shops in Dapitan City, most of these shops sell ready to wear items (such as shorts, shirts, dresses, hats, bags, etc) printed with the most famous scenic spots in the locality, key chains, and delicacies produced by the local residents such as the famous banana and cassava chips and bottled sardines. 
Table 3. Inventory of Souvenir Shops in Dapitan City (2018)

\begin{tabular}{|l|l|l|}
\hline No & Name & Location \\
\hline 1 & Alfredo Souvenir Shop & Brgy. Talisay \\
\hline 2 & Ashley Souvenir Shop & Brgy. Talisay \\
\hline 3 & Dapitan Souvenir Shop & Brgy. Dawo \\
\hline 4 & Erlinda's Food House & Brgy. Dawo \\
\hline 5 & Flora's Souvenir Items & Brgy. Talisay \\
\hline 6 & Four J's Souvenir Shop & Brgy. Talisay \\
\hline 7 & Harnie Souvenir Shop & Brgy. Sta. Cruz \\
\hline 8 & Harnie Souvenir Shop - Peddler & Brgy. Talisay \\
\hline 9 & J.e Souvenir Store & Brgy. Talisay \\
\hline 10 & LGS Store II & Brgy. Talisay \\
\hline 11 & Mcvince Souvenir Store & Brgy. Talisay \\
\hline 12 & Mencho Souvenir Items & Brgy. Talisay \\
\hline 13 & Nanay's Souvenir Shop & Brgy. Talisay \\
\hline 14 & Phoeb's Store & Brgy. Talisay \\
\hline 15 & Rhianna Rain Souvenir Store & Brgy. Talisay \\
\hline 16 & Sagittarius Souvenir Shop & Brgy. Sta. Cruz \\
\hline 17 & Shrine Souvenir Shop & Brgy. Dawo \\
\hline 18 & Tatxmarj Print Shoppe & Brgy. Sicayab Bucana \\
\hline 19 & Vic Souvenir Store & Brgy. Talisay \\
\hline
\end{tabular}

Source: Business Permits and Licensing Office

Figure 3. Number of Tourism-related Businesses in Dapitan City (2017-2019)

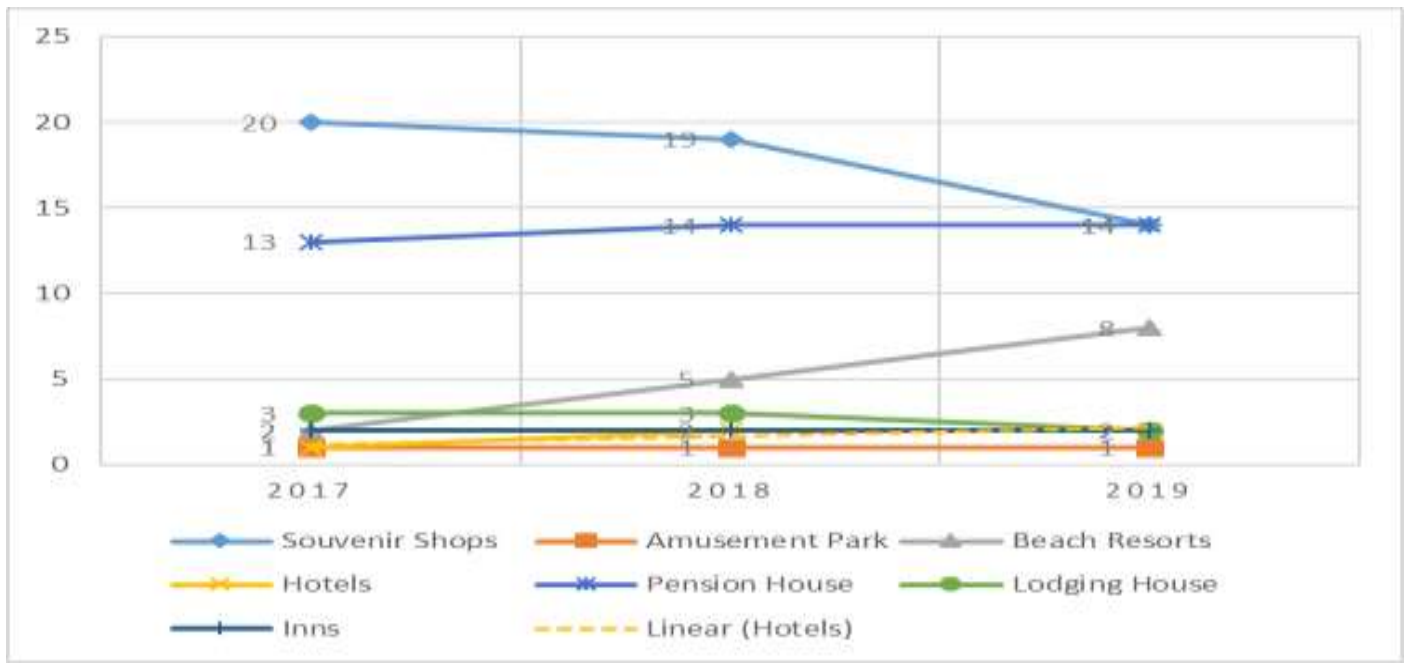

Source: Business Permits and Licensing Office

Figure 3 shows the trend of the number of tourism-related businesses in Dapitan City since 2017-2019. It can be seen that number of pension houses, beach resorts, hotels projects a positive trend while the number of souvenir shops and lodging houses shows a negative trend. Further, the number of amusement park and inns remains the same within the last three years. It should be noted that data on other tourism-related sectors such as food and beverage, transportation companies, and travel agencies were not included due to inavailability.

Based on the site evaluation form adapted from the Tourism Guidebook for LGUs, Figure 4 shows the top ten tourist sites in Dapitan City which gained the highest scores when evaluated using the following criteria: 1. Uniqueness and natural beauty, 2. Historical and Cultural value, 3. Accessibility, 4. Availability of Basic Utilities, 5. Availability of Onsite Facilities, 6. Ownership of Property, 7. Quality of surroundings. 
There were a total of forty (40) tourist sites evaluated and first in rank is Dakak Park and Beach Resort having the highest score of 133 points. This is evidenced by the capability of the resort to lead the market through development of competitive and quality tourism products. Second in rank is St. James Church with a score of 130 points, and Don Aniano Adasa Heritage House ranks third with 128 points. These two attractions were among the top of the list because of their historical and cultural significance not to mention the basic facilities available on these sites.

\section{Figure 4. Top 10 Tourist Sites According to Certain Criteria}

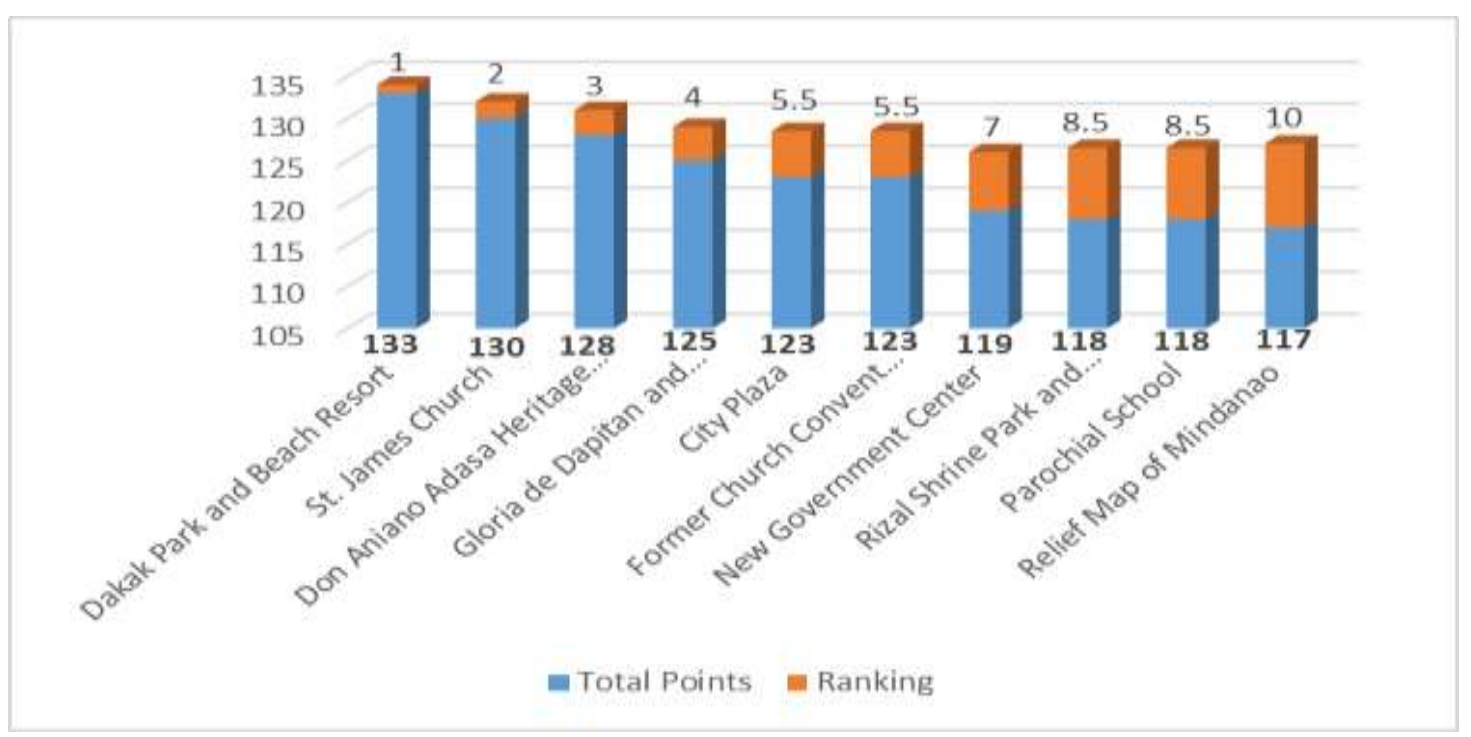

Gloria de Dapitan, although ranks first in terms of tourist arrival, only got the fourth place with 125 points as it scored low in the aspect of historical and cultural value. The City Plaza and the former Church Convent (now the Rizal Memorial Institute Library) got the fifth place having the score of 123 points. The new government center follows at the sixth place having 119 points. Rizal Shrine Park and Museum, being the second most visited place in the region is only at the seventh place because it has poor tourist facilities and utilities available on the site. On the same spot is the Parochial school garnering 118 points. Lastly, the Relief Map of Mindanao got 117 points making it at the tenth rank. This table provides a different lens on how tourist attractions should be developed based on the seven criteria mentioned above.

Natural heritage refers to any natural object or place that has unique aesthetic value enough to lure the eyes of the tourists. As per site assessment using the tool from the Local Tourism Guidebook, among the eight sites identified under natural heritage category, Ilihan Hill ranks first with 113 points and Dapitan River ranks second with 111 points as seen in Table 5. Both sites offer unique natural beauty and good quality of surroundings and but the latter is rated in the low in terms of historical and cultural value. Both are easily accessible since it is located in the heart of the city but they have poor onsite facilities.

Ambakon Spring and Green Resort and Taguilon got the third and fourth place with 104 and 103 points respectively. Coastal Beaches ranks fifth with 101 points followed by Grotto of Our Lady of Lourdes with 93 points bagging the sixth place. The last two sites Dapitan and Mt.

\section{Infrastructure}

Transportation is a key factor for any tourism development. Table 9 presents the details of transportation available in Dapitan City. It has a domestic seaport which facilitates access to tourists coming from the Luzon and Visayas Region using the western route of Strong Republic Nautical Highway - RORO. Dapitan can also be accessed by plane via Dipolog domestic airport which offers daily flights going to Cebu City and Metro Manila, respectively. Bus transportation is also available everyday but the most frequent trips going in and out of Dapitan is through the coaster bus of the Evergood Transit Inc. 
Table 4. Available Transportation To and From Dapitan

\begin{tabular}{|c|c|c|c|}
\hline Type & Schedule & Route & Average Fare \\
\hline $\begin{array}{c}\text { Coaster } \\
\text { (Evergood } \\
\text { Transit) }\end{array}$ & Daily & Dapitan - Dipolog v.v. & Php 30.00 (one-way) \\
\hline $\begin{array}{c}\text { Bus (Rural } \\
\text { Transit) }\end{array}$ & Daily & $\begin{array}{c}\text { Dipolog - Plaridel, Oroquita, } \\
\text { Ozamiz v.v. }\end{array}$ & Php 250.00 (one-way) \\
\hline \multirow[t]{2}{*}{ Tricycle } & \multirow[t]{2}{*}{ Daily } & Within city proper & Php $8.00-10.00$ (one-way) \\
\hline & & $\begin{array}{c}\text { City-proper to Puluan port } \\
\text { v.v. }\end{array}$ & Php 50.00 (one-way) \\
\hline \multirow[t]{3}{*}{ Ship } & \multirow[t]{2}{*}{ Daily } & Dapitan - Dumaguete v.v & Php 450.00 (one-way) \\
\hline & & Dapitan - Cebu v.v & Php 850.00 (one-way) \\
\hline & Wednesday & Dapitan - Manila vv & Php 3,130.00 (one-way) \\
\hline \multirow[t]{2}{*}{ Plane } & \multirow[t]{2}{*}{ Daily } & Dipolog-Manila v.v & \multirow{2}{*}{$\begin{array}{l}\text { Ranging from Php 3,500.00 } \\
\text { - Php9,000.00 (one-way) }\end{array}$} \\
\hline & & Dipolog - Cebu v.v & \\
\hline
\end{tabular}

\section{Power and electricity}

The city's power needs are supplied by the Zamboanga del Norte Electric Cooperative (ZANECO) which draws its supply from the National Grid Corporation of the Philippines (NGCP). Generally stable at 220volts and 60 cycles, occasional power outages however occur when there are material disruptions along the main feeder lines. Rotational brownouts are enforced when power supply becomes critical. Rates are among the highest in the region.

\section{Water}

Lamentably, the Dapitan City Water District has not yet found alternative sources of Water that would meet the required volume for the city proper. The Dapitan river and the Talyaman Watershed are inadequate and household taps practically run dry during prolonged days of sunshine, and frequently discolored or hazy when it rains. Bigger pipelines have recently been laid to draw water from Barangay Potungan or Baao but it may take some time before the city will enjoy uninterrupted and safe waters supply. Rates are inversely proportional to the availability of clean water. In the meantime, purified drinking water is supplied by dozens of water filtration and refilling stations all over the city.

\section{Other Support Services}

Table 5. Tourism Education

\begin{tabular}{|c|c|c|c|c|}
\hline Title of training & Date/venue & $\begin{array}{c}\text { \# of } \\
\text { Participants }\end{array}$ & $\begin{array}{l}\text { Participant } \\
\text { Group }\end{array}$ & $\begin{array}{l}\text { Organized/ } \\
\text { conducted by }\end{array}$ \\
\hline $\begin{array}{l}\text { Hospitality Related } \\
\text { Service }\end{array}$ & $\begin{array}{c}\text { June } 1 \text { - July 20, } \\
2016 \text { / Barangay } \\
\text { Hall }\end{array}$ & 186 & $\begin{array}{c}\text { 4Ps Members of } \\
\text { Brgy. Bagting, } \\
\text { Brgy. Sta Cruz, } \\
\text { Brgy. Potol, } \\
\text { Brgy. Linabo }\end{array}$ & $\begin{array}{l}\text { Tourism and } \\
\text { Hospitality } \\
\text { Management } \\
\text { Department, } \\
\text { JRMSU }\end{array}$ \\
\hline $\begin{array}{l}\text { Community-tour } \\
\text { guiding }\end{array}$ & $\begin{array}{c}\text { April 12-July 10, } \\
2017 \text { / } \\
\text { Gloria De } \\
\text { Dapitan }\end{array}$ & 38 & $\begin{array}{c}\text { Sunset } \\
\text { Boulevars } \\
\text { Tricycle } \\
\text { Operators and } \\
\text { Drivers } \\
\text { Association }\end{array}$ & $\begin{array}{c}\text { Tourism } \\
\text { Department, } \\
\text { JRMSU }\end{array}$ \\
\hline $\begin{array}{l}\text { Courses on Front } \\
\text { Office Operations } \\
\text { and Housekeeping } \\
\text { Services with } \\
\text { Service Excellence } \\
\text { in Tourism }\end{array}$ & $\begin{array}{l}\text { 07-11 August } \\
\text { 2017, Dakak Park } \\
\text { and Beach Resort }\end{array}$ & 49 & $\begin{array}{c}\text { Dakak Park and } \\
\text { Beach Resort, } \\
\text { DAMPA, GDD, } \\
\text { Frontliners }\end{array}$ & DOT R-9 \\
\hline
\end{tabular}




\begin{tabular}{|l|l|c|l|l|}
\hline $\begin{array}{l}\text { Community Guiding } \\
\text { Seminar }\end{array}$ & $\begin{array}{l}\text { October 6-12, } \\
\text { 2017, Alexandra } \\
\text { by the Sea, } \\
\text { Dapitan City }\end{array}$ & 25 & $\begin{array}{l}\text { Rizal Shrine, } \\
\text { JRMSU, CTO }\end{array}$ & DOT R-9 \\
\hline $\begin{array}{l}\text { Community Guiding } \\
\text { Seminar }\end{array}$ & $\begin{array}{l}\text { June 19-25, 2018, } \\
\text { Bajamunde Farms } \\
\text { Pension House, } \\
\text { Dapitan City }\end{array}$ & 20 & $\begin{array}{l}\text { Rizal Shrine, } \\
\text { CTO, Private } \\
\text { Individuals }\end{array}$ & DOT R-9 \\
\hline $\begin{array}{l}\text { Course on Waitering } \\
\text { with Service } \\
\begin{array}{l}\text { Excellence in } \\
\text { Tourism }\end{array}\end{array}$ & $\begin{array}{l}\text { November 13-15, } \\
\text { 2018, } \\
\text { Dakak Park and } \\
\text { Beach Resort }\end{array}$ & 36 & Dakak and GDD & DOT R-9 \\
\hline $\begin{array}{l}\text { Basic Wine Service } \\
\text { And Bartending } \\
\text { With Mixology }\end{array}$ & $\begin{array}{l}\text { July 16-18, 2019, } \\
\text { Dakak Park and } \\
\text { Beach Resort }\end{array}$ & 33 & Dakak and GDD & DOT R-9 \\
\hline
\end{tabular}

Sources: JRMSU and DOT Region 9

The quality of tourism services is affected by the level of knowledge and skills the Table 5 presents the various tourism related trainings and seminars conducted by different agencies to enhance the skills and knowledge of workers working under the tourism industry. It can be seen that in 2016 and 2017, there are two tourism related trainings done by Jose Rizal Memorial State University in fulfillment of their core function which is community extension. First training is the hospitality service which was provided to the 4Ps beneficiaries of the Poblacion barangays and second is the community tour guiding given to the Sunset Boulevard Tricycle Operators and Drivers Association (SBTODA) to enhance their capabilities to perform local tours providing them more economic opportunity.

Further, the DOT Regional Office also spearheaded trainings geared towards enhancing the quality of tourism services especially those in the frontline operations. Three in 2017 ( 2 of which is related to improving hotel services and 1 on community tour guiding, Two (2) in 2018 and 1 (one) in 2019.

Based on these findings, the trainings are more concentrated in developing only the accommodation sector and tour operators. Further, there are only two government agencies organizing trainings, JRMSU and DOT Region 9. Thus, provision of more intensive and practical trainings that should be able to enhance the entire tourism sector (i.e., food and beverage service, tourist information services, transportation services) is indeed necessary.

Figure 6 illustrates the peace and order situation of Dapitan city as represented by the number of index and non-index crimes for the last 5 years, from 2014-2018. It can be seen that crimes classified as non-index crimes reached to 358 in year 2016 then went down to 279 in 2017 but went high again to 331 the following year. as compared to 210 reported in the previous year an.

Figure 6. Peace and Order Situation in Dapitan City (2014 - 2018)

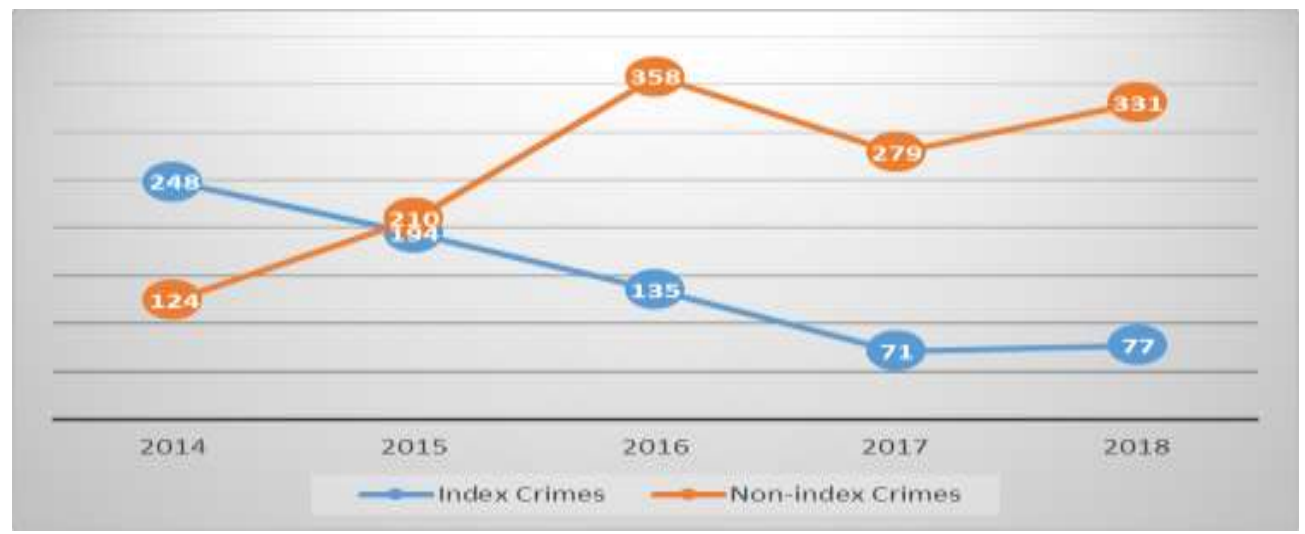


According to the PNP, this fluctuation can be attributed to the national and local election held last 2016 and in. On the other hand, it is important to note that PNP Dapitan has been successively the recipient of the BEST PNP Award for the past five years which is an evidence of their untiring efforts to keep the city peaceful and secure.

As a matter of fact, many significant foreign personalities were able to visit and explore Dapitan's heritage among of which is the 2019 Russian Ambassador, the Austrian and German Ambassadors (2008), Czech Republic Ambassador, the Mayor of Litomirice. Recently, the Philippine's Miss Universe Candidate 2019 visited and showcased the city in her advocacy. Further, international business conferences and events such as the reunion of the 2014 Queens of the Universe was also held in Dapitan City last 2019. With all these, it can be concluded that Dapitan City is the safest city in the entire region of Zamboanga Peninsula.

Generally, in Dapitan City crime rate is relatively low and hardly any record of heinous crimes committed for a number of years now particularly those committed under the influence of drugs and alcohol. Most crimes center on thief and petty thieveries. Traffic violations and vehicular accidents are also the most common occurrences that sometimes stir the tranquility of the City. With regards to safety and security of visitors, it can be inferred that Dapitan City is one of the safest destinations to visit on earth.

\section{Market Profile of Dapitan City}

Tourist(s) refers to the person or group who spends an overnight stay outside their usual environment (DOT). Figure 7 presents the volume of tourist arrivals in Dapitan City for the period $2014-2018$ based on the data gathered from Dapitan City Tourism Office. It can be seen that although there is an upward trend, the numbers of both domestic and foreign tourists are very low when compared to other tourist destinations in the country (see Figure 3).

\section{Figure 7. Inventory of Tourist Arrivals (2014-2018)}

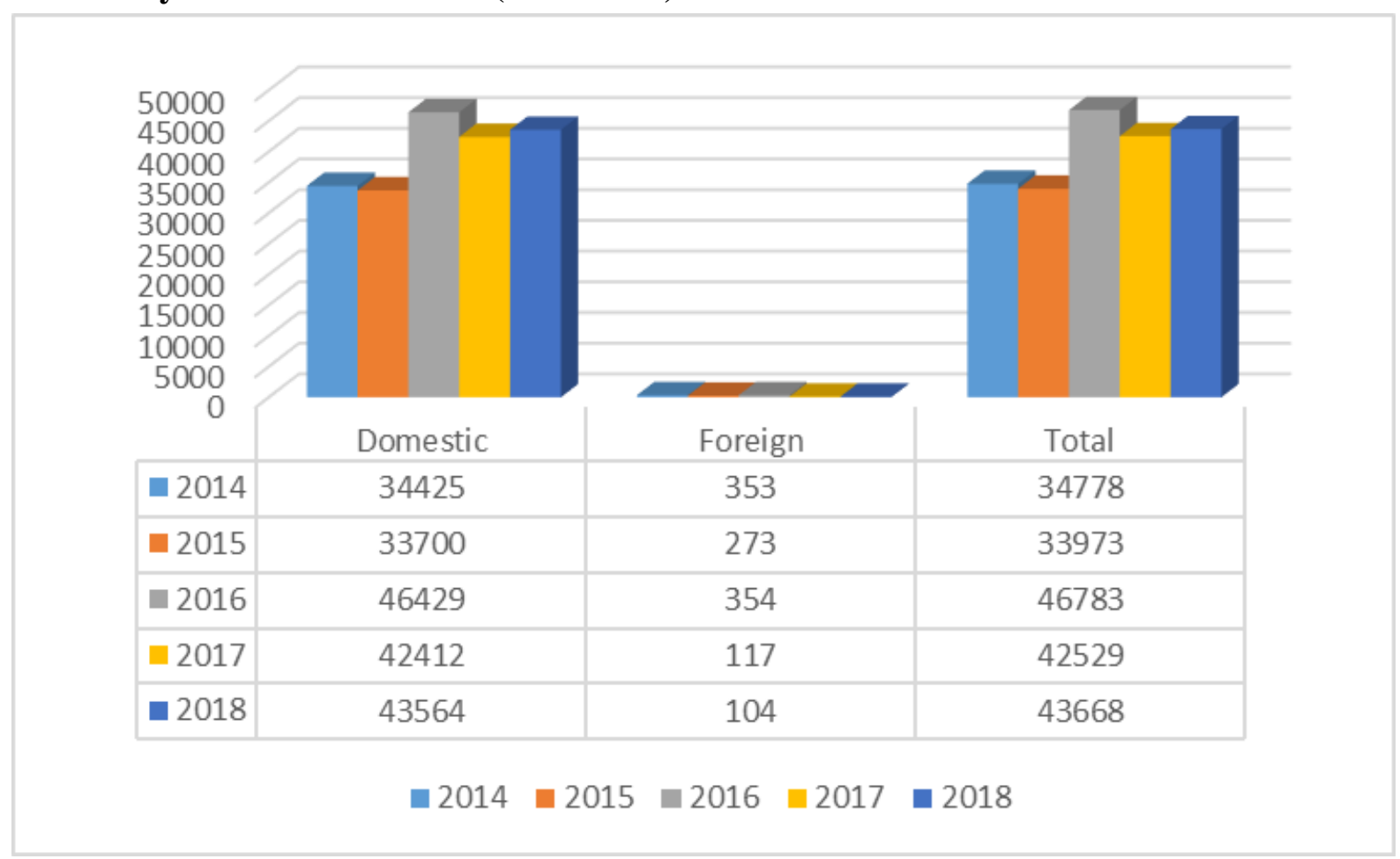

Source: Dapitan City Tourism Office, December 2019

For the past five years only an average of 40,346 tourist stays in the city overnight. The data was taken from the accommodation facilities excluding Dakak Park and Beach Resort due to its inavailability. This data reveals the urgent need for the local government unit to develop and create competitive strategies if it wants to capitalize on tourism as an engine for sustainable development. The market shares as represented by the 
number of tourist arrivals in the destination is a vital indicator in measuring success in tourism (UNWTO, 2017).

Thus, if it goes on a steady pace for the past five years, then it is high time to strengthen the city's marketing efforts particularly targeting the foreign market. On the other hand, the data illustrates the incontestable potential of Dapitan to draw tourists and visitors despite the threats on environmental hazards, safety and security.

Figure 8 shows the high inventory of visitor arrivals in Dapitan City since $2014-2018$ domestically. Visitor(s) refers to a person or group who came to visit at least one of the tourist sites in the city for less than 24 hours and did not stay overnight (DOT, 2019). The city caters to approximately 1.5M(average) domestic visitors every year and only 0.05 percent foreign visitors. The high visitor performance can be attributed to the presence of Gloria de Dapitan and Rizal Shrine being the top 2 tourist attractions in the region.

It can be seen that there is huge disparity between the number of tourists who stay overnight (see Figure 7) and the number of visitors. This is due to the fact that Dapitan at night time is more calm and peaceful than its neighboring city, Dipolog which is livelier because it has more night bars.

Figure 8. Inventory of Visitor Arrivals (2014-2018)

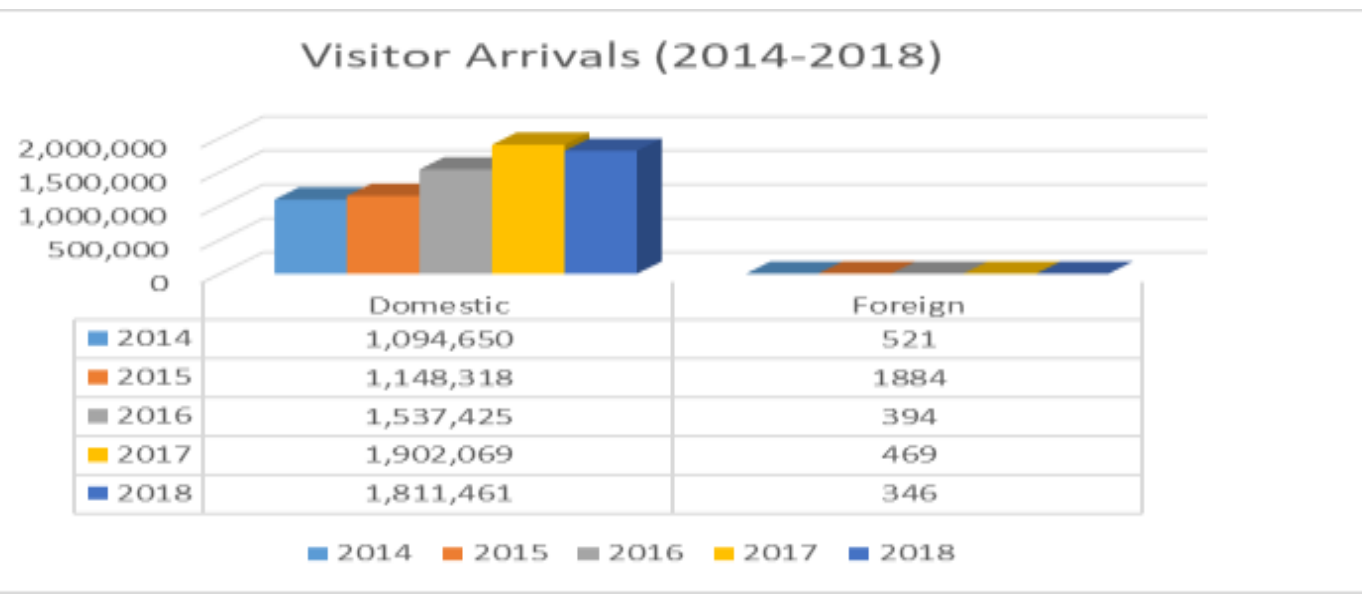

Source: Dapitan City Tourism Office, December 2019

In addition, airport and bus terminals are located in Dipolog which makes it a more preferable place to stay. So, usually visitors come to Dapitan during the day and stay in Dipolog at night. This result provides an insight of the consumption pattern of tourists which should be given focus and attention when developing strategies for Dapitan's tourism.

Table 6. List of Top 10 Tourist Attractions in Region 9 based on Tourist Arrivals (2018)

\begin{tabular}{|c|r|r|}
\hline RANK & \multicolumn{1}{|c|}{ NAME OF TOURIST ATTRACTION } & $\begin{array}{c}\text { TOTAL ARRIVALS } \\
2018\end{array}$ \\
\hline 1 & Gloria de Dapitan Tourism Entertainment Complex & $\mathbf{1 , 5 3 7 , 6 6 4}$ \\
2 & Rizal Shrine & 194,878 \\
3 & Mt. Tambulig Mountain Resort & 154,647 \\
4 & Aurora Mountain Resort & $\mathbf{8 9 , 2 1 6}$ \\
5 & Sta. Cruz Pink Island & $\mathbf{8 3 , 3 8 7}$ \\
6 & Eriberta Spring Resort & $\mathbf{4 7 , 2 8 8}$ \\
7 & White Beach Resort, Malamawi Island & $\mathbf{4 3 , 9 6 4}$ \\
8 & Mabanag Spring Resort & $\mathbf{3 1 , 4 9 2}$ \\
9 & Buluan Island & $\mathbf{1 9 , 0 3 3}$ \\
10 & Alindahaw Lakeview Resort & $\mathbf{1 7 , 5 6 6}$ \\
\hline
\end{tabular}


Taking a broader look of tourism industry's performance, Figure 9 shows the distribution of volume of tourists in the entire region. Dapitan City got the third place having more than 100k tourists. It can be inferred that the strongest competitors of Dapitan are. Zamboanga City, taking the lead by having almost 500K tourists last 2018, and Dipolog City with more than 200k tourists.

Figure 9. Comparative Data Among Cities and Provinces in Region 9 as per Tourist Arrival (2018)

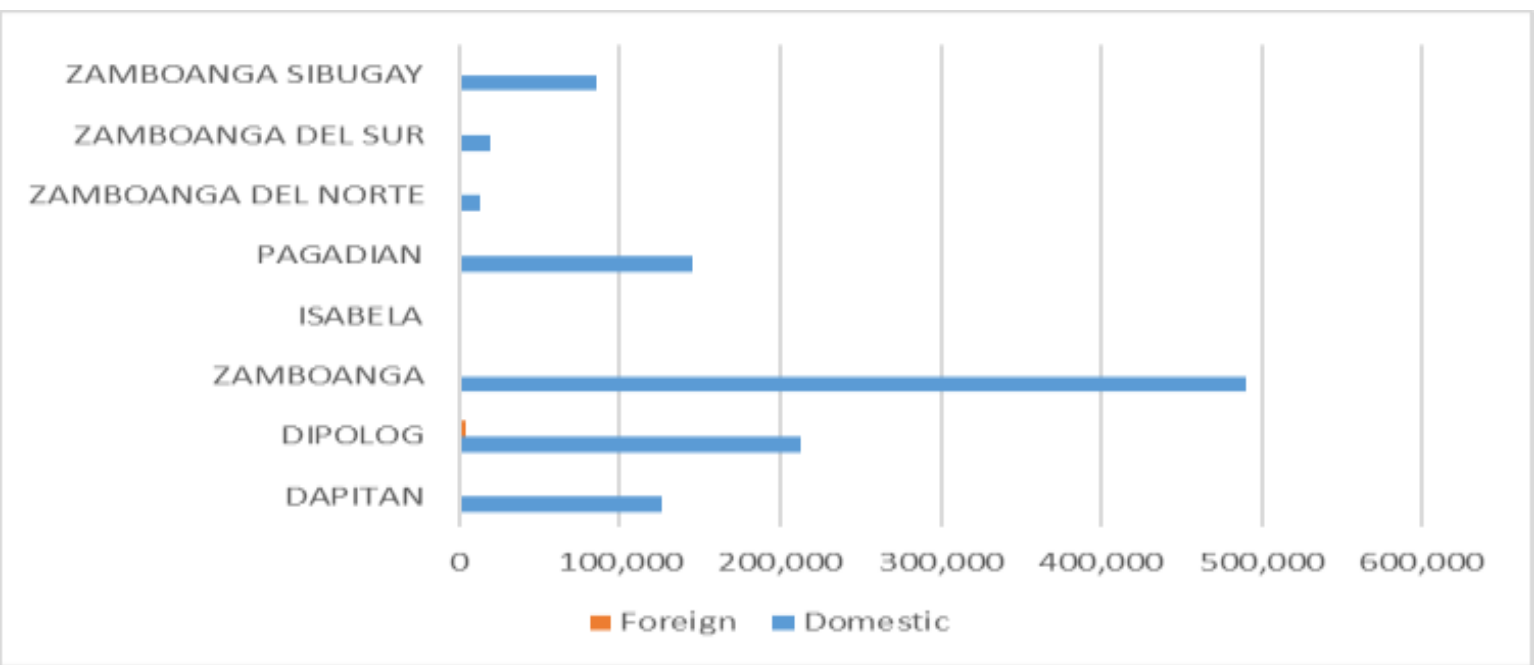

Source: DOT Region 9, 2019

Figure 10 shows the number of foreign tourist arrivals in Region 9 based on their country of origin. It could be seen that USA got the highest number of 2,639 followed by China with 2,321 and Malaysia ranked third with 1,709 tourists. With this, it can be inferred that Americans and Asians are the primary markets to cater when developing our tourism products and services.

Figure 10. Top 10 Foreign Tourist Arrivals in Region 9 (2018)

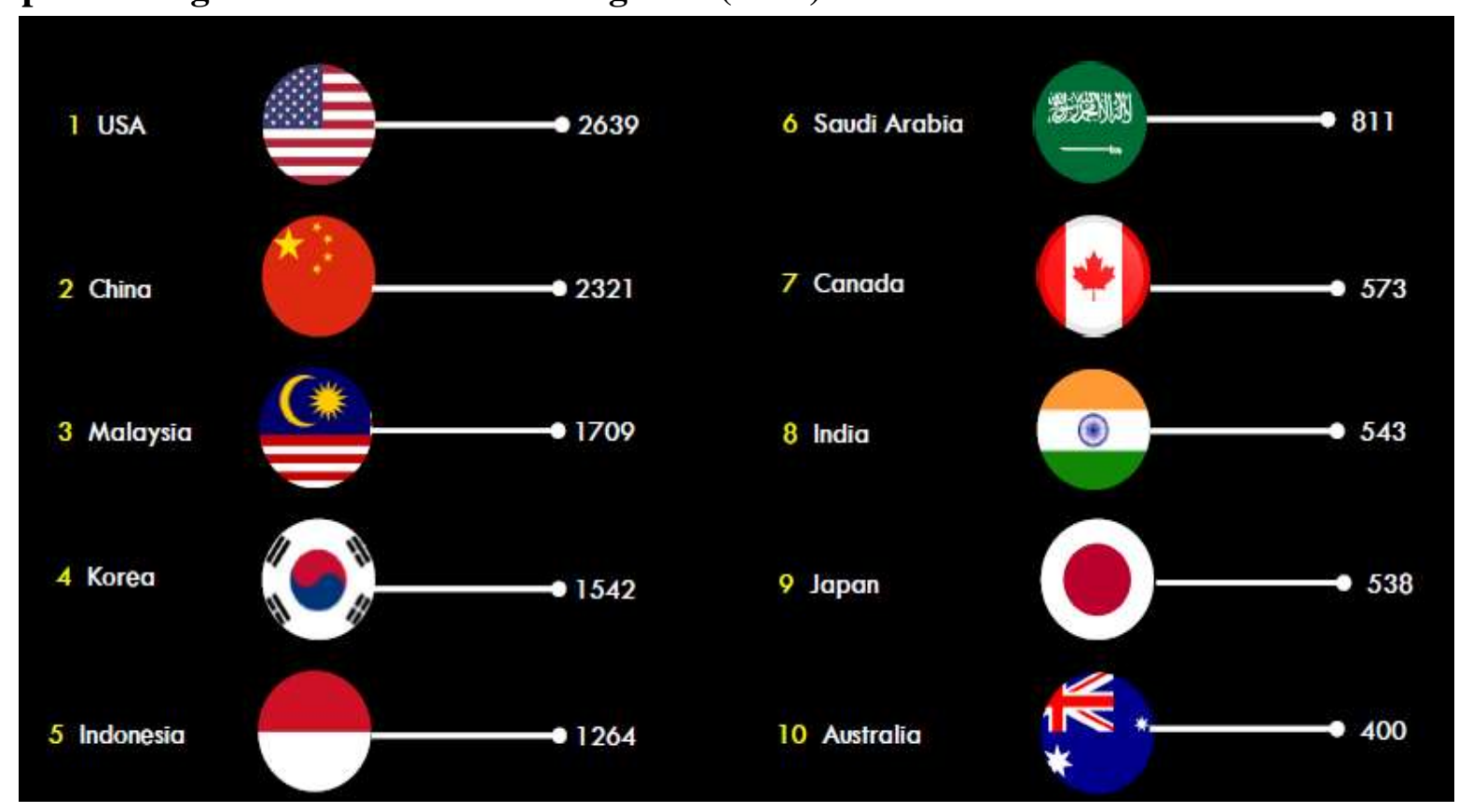

Source: DOT Region 9, 2019

\section{Conclusion}


Tourism industry can be an engine of local economic growth and the same time preserve and promote its natural resources and culture heritage if it can be managed well. Dapitan City is endowed with such beautiful natural attractions and in fact, enjoys a distinctive, historical and cultural heritage which cannot be found in other tourist destinations. Tourism resources are rich but there are limited amenities that can cater to the visitor demands. The supply of accommodation services is insufficient and only offers the basic. Thus, there is a need to encourage increase investment in the private sector. Moreover, there is a greater need for the local government to enhance their support in terms of infrastructure and other support services especially on the basic services such power and water supply, communication and transportation facilities to provide better services and experience to our guests and visitors. Considering these rich assets of nature and heritage, the study recommends that future development plans could focus on development of ecotourism, agritourism and heritage tourism. On the other hand,

There are several limitations of the study. First is the lack of data in several aspects of the study which includes the data on food and beverages, travel intermediaries, market profile, other infrastructures, support services. Analysis related to the food and beverage sector and travel intermediaries were not included in the study as there is difficulty in accessing the historical data from the offices concerned. The market profile analysis is limited to the secondary data on the regional tourist arrival which is not sufficient to analyze the overall market profile. Specific data on the visitor's length of stay, travel options availed, satisfaction surveys, and tourist preferences and the like are not included in the study. Second, there is lack of participation and interest of some government officials and representatives during data gathering which resulted to having the limited information on key aspects of the industry. Third, leisure and recreation aspects of tourism was also not included. Future studies can be conducted addressing the limitations of the study.

\section{References}

1. Aynalem S, Akele B, Alemayehu H, Molla G (2015) Assessment and Identification of the Tourism Resources of Bale Zone, Ethiopia. J Tourism Hospitality 4: 176. doi:10.4172/21670269.1000176

2. Chen, Y.; Li, Y.; Gu, X.; Chen, N.; Yuan, Q.; Yan, M. Evaluation of Tourism Development Potential on Provinces along the Belt and Road in China: Generation of a Comprehensive Index System. Land 2021, 10, 905. https://doi.org/ 10.3390/land10090905

3. Department of Tourism (2017). https://beta.tourism.gov.ph/

4. Kisi, N. (2019). A Strategic Approach to Sustainable Tourism Development Using the A'WOT Hybrid Method: A Case Study of Zonguldak, Turkey. MDPI Sustainability Journal. DOI:10.3390/su11040964

5. Nasa, M., and Hassan, F.B., (2016). Assessment of Tourism Resource Potential at Buriram Province, Thailand, Asian Social Science; Vol. 12, No. 10; doi:10.5539/ass.v12n10p27

6. Wang, S. L., (2016). Analysis of the economic principles of tourism resource development by using the sustainable development view. Education for Chinese After-school (Theory), 15:101

7. Wang, J., Huang, X., Gong, Z., and Cao, K. (2019). Dynamic assessment of tourism carrying capacity and its impacts on tourism economic growth in urban tourism destinations in China. Journal of Destination Marketing \& Management. https://doi.org/10.1016/j.jdmm.2019.100383

8. Lopez, P.B., Solis, V.V., Aguero, J.A.R., And Chavez, M.G.G., (2019). Inventory Of Tourism Resources As A Basis For Territorial Planning In Zona Altiplano Of San Luis Potosí, Mexico. Cuadernos de Turismo, 35, (2015); pp. 427-430

9. United Nations World Tourism Organization (2019). https://www.unwto.org/

10. World Tourism Barometer (2017). https://www.eunwto.org/doi/abs/10.18111/wtobarometereng.2017.15.6.1? journalCode=wtobaromete reng

11. Indian National Trust for Art and Cultural Heritage (INTACH) (2016).

12. RA 9593, Chapter II. Tourism Governance, Subchapter 11-E. Shared Responsibilities Of National And Local Governments, Section 41. Local Government Capabilities Enhancement.

13. Travis, A., 2011. Planning for Tourism, Leisure and Sustainability: International Case Studies, Wallingford: CAB International

14. Zhao, M. (2015). The intensive sustainable development of China's Rural Tourism under the perspective of Ecological Civilization. Agricultural Economy, 11:58-59 